\title{
Jean Leo Testut (1849-1925): anatomist and anthropologist
}

\author{
Rafael Romero Reverón* \\ Human Anatomy Department, 7.M. Vargas School of Medicine, Universidad Central de Venezuela, Caracas, Venezuela
}

\begin{abstract}
Leo Testut (1849-1925), professor of human anatomy of the Faculty of Medicine of Lyon, wrote more than 90 publications on anatomy, anthropology and history, the most outstanding of which was his treatise on human anatomy published in 1887. He founded and directed the International Journal of Anatomy and Histology. He was a member of the French Academy of Medicine and president of the World Association of Anatomists.
\end{abstract}

Keywords: anatomist; anthropology; history; human anatomy; Jean Leo Testut

Anatomy 2014;8:36-39, (C) 2014 TSACA

\section{Introduction}

Jean Leo Testut (Figure 1) was a medical doctor, an outstanding anatomist, a professor of human anatomy and also an anthropologist. His works still constitute basic and important references in text books or consultation books in the study of human anatomy in medical schools of universities in Latin America and Europe. The objective of this paper is to make a brief review Leo Testut's life and his contributions to human anatomy.

\section{Childhood and Education}

Jean Leo Testut Deynat was born on March 22, 1849 in Saint Avit Senier, France. His parents were Jean Testut and Marie Deynat. Jean Leo Testut had his basic education in a small seminary of Bergerac, and later he studied at the high school in Sarlat. Jean Leo Testut started his medical studies in Bordeaux, but was forced to suspend them at the onset of the 1870 Franco-Prussian war. He was drafted into the army and went into battle, and was deployed as an assistant major in the Dordogne Mobiles regiment. Together with Doctor Barraud, they took care

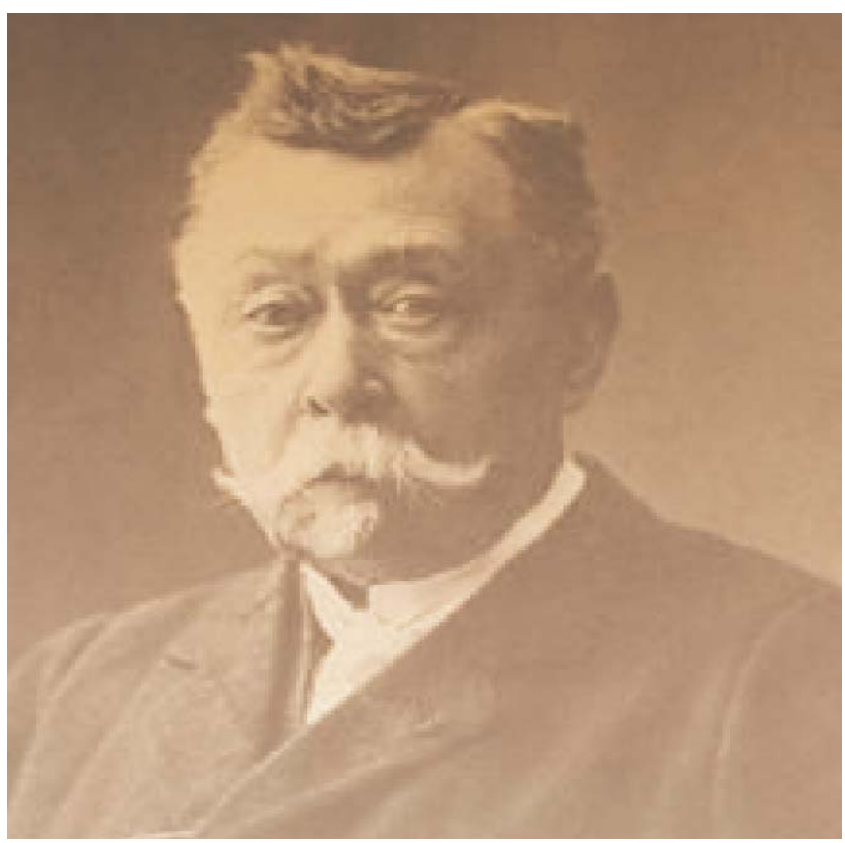

Figure 1. Leo Testut (1849-1925). http://livre.histoire.free.fr/fichiers/ personne/testut.jpg (accessed in Nov 04, 2013)

\footnotetext{
*Numerary Member of the Venezuelan Society of the History of Medicine; Member of the International Society of the History of Medicine, Member of the American Association of the History of Medicine; Medical Doctor, Specialist in Orthopedic Trauma Surgery at the Centro Médico Docente La Trinidad and Urologico San Román, Caracas, Venezuela
} 
of General de Sonis inthe battle of Loigny. Testut was presented with the Legion of Honor commemoration medal for his courage and patriotism -which he refused to accept- and later received the civilian version of that medal. Once the Franco-Prussian war ended, Jean Leo Testut (better known by his second name Leo) went back to study at the School of Medicine of Bordeaux in $1878^{[1]}$ and upon concluding his studies, presented a voluminous postdoctoral thesis entitled: "On symmetry in skin ailments: A physiological and clinical study of the similitude of homologous regions and paired organs", which was recognized and awarded the silver medal of the Faculty of Medicine of Paris, the Godard prize of the French Academy of Medicine, and the gold medal of the Academy of Sciences of Bordeaux.

\section{The Anatomist}

From 1872 to 1878 , he worked at the universities of Bordeaux and Paris, supplementing his academic training in anatomy in Paris, working at the Broca and the Pouchet laboratories where he researched comparative anatomy. ${ }^{[2]}$ Testut was assistant chief of anatomy and physiology at the Faculty of Medicine of Bordeaux from 1878 to 1884 and was named head of anatomical studies at the same faculty. In 1880, he wrote "Vessels and nerves in conjunctive, fibrous, serous and bone tissues: anatomy and physiology", which constituted the thesis presented to opt for the position at the school of anatomy and physiology of the Faculty of Medicine of Bordeaux. In 1883, he drafted the "Study on the longitude of the flexor proper of the pollicis (thumb) in men and monkeys", published in Bulletin of the Zoological Society of France. Testut set up his practice in Lille in 1884, where he worked as an associate professor at Lille University.

Leo Testut published a paper in 1884 entitled "The brachialis portion of the musculocutaneous nerve" which gave origin to the eponym "nerve of Testut". In 1887, he published a paper entitled "What is man to an anatomist?", an inaugural lesson for the course in anatomy at the Faculty of Medicine of Lyon. That same year, Professor Testut published his outstanding four-volume Treatise on human anatomy, and a second edition in 1893 , considered as one of the most comprehensive treatises on human anatomy. ${ }^{[3]}$ This work was awarded the Saintour Prize in 1902 by the French Academy of Medicine (Figure 2). This treatise on human anatomy is still current even one century after its initial publication, and continues to be used as a textbook or consultation book in many faculties of medicine in Latin America and Europe. ${ }^{[4]}$ Since 1910, this treatise on human anatomy has been translated from French to Spanish, Italian, German and other languages. As a teacher, Professor Leo Testut was characterized for his punctuality, firm and paused voice, as well as his precise descriptions of the human body, enriched by anthropological and philosophical concepts. He was a professor at the Faculty of Medicine of Lyon from 1886 to 1919 . He received the "honorary professor" title in 1919. The French Academy of Medicine named Leo Testut a correspondent member in $1895 .{ }^{[5]} \mathrm{He}$ also acted as the president of the World Association of Anatomists. In 1905, in collaboration with Octavio Jacob and Henry Billet, Leo Testut published the 'Atlas of Dissections by Regions', a very useful guide that directs and illustrates each stage of human anatomical dissection, with 72 color slides and 68 figures. In collaboration with Octave Jacob, Leo Testut published a two-volume treatise on topographical anatomy with medical-surgical applications in 1909 (Figure 3). This work received the Montyon Award by the French Academy of Sciences in 1911 and the Saintour Award by the French Academy of Medicine in 1912. Together with André Latarjet, Leo Testut published the 'Compendium of Descriptive Anatomy' in 1921. The eighth edition of his 'Treatise on Human Anatomy' was commenced the year of his death in 1925 and incorporated the works of André Latarjet, who took charge of future editions of the text. This treatise on human anatomy is characterized for its precise descriptions of the human body, enriched with anthropological and philosophical concepts and excellent drawings. ${ }^{[6]}$ A posthumous book written by Leo Testut and Jean Pitres entitled "The Nerves and their Schematics" was published in 1925.

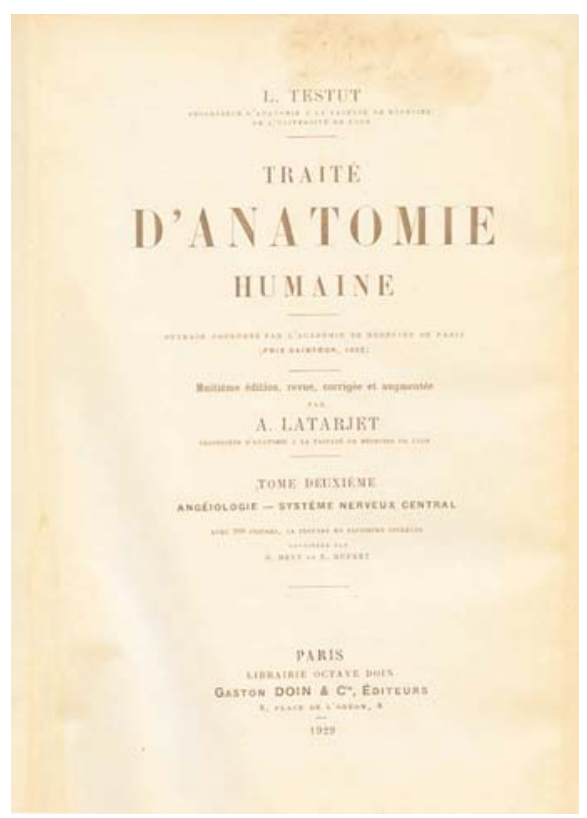

Figure 2. Treatise on human anatomy; Testut L, Latarjet A (1929). http://www.le-livre.fr/Livre-R160128826.html (accessed in Feb 09, 2014). 


\section{The Anthropologist}

Testut completed studies on anthropology at the Quatrefages laboratory, supplementing his academic training in anatomy in Paris. ${ }^{[2]}$ In 1884, Leo Testut published the paper "Muscular anomalies in man, explained by comparative anatomy and its importance in anthropology". This study presented a classification based on individual and regional influences of heredity on variations of the muscular system. This paper received the Broca Award in 1885 granted by the Society of Anthropology of Paris, the Chateauvillars Prize granted by the Faculty of Medicine of Paris and the Montyon Prize by the Institute of France. He also wrote articles on anthropological anatomy between 1875 and 1890, including 'The dissection of a Bosquiman', 'Muscular anomalies in individuals of African and Caucasian descendance', as well as 'Myology and observations of muscular anomalies studied in an individual of African descendance in Borbon island'. Testut published the paper" Excavations in the caverns of Lavigne and Pèbousquet, Lower Pyrenees" in the Bulletin of the Bordeaux Society. He also published the paper 'New excavations in the Saint-Sulpice station, Lalinde canton, Dordogne' in the Bulletin of the Society of Bordeaux and 'The Prehistoric Necropolis of Nauthèry, in the area of the Landas canton'. He also conducted an experimental study on the muscles of the grizzly bear of America. ${ }^{[7]} \mathrm{In}$ 1883, Testut, in the company of Captain Mason and Bracquemont, excavated the caverns of the Sauci station, where he found numerous flints of quartz and carved bones from the last Paleolithic period (Figure 4). In 1884, he published a study on the Cave of the Wolf of Langlade in Saint-Amand de Belvès in the Bulletin of the Society of Anthropology of Bordeaux. Next, with Tallebois and Dufource, he studied the burial grounds of the first Iron Age in the Lower Pyrenees region. In 1888, Testut exhumed and undertook the anthropological study of the skeleton discovered by Michael Hardy and Maurice Fèaux, which was in a forced position on its left side and covered in red ochre, demonstrating it was an intentional burial. This work was published in the Bulletin of the Society of Anthropology of Lyon under the title: "Anthropological investigations on the quaternary skeleton of Chancelade". Leo Testut also collaborated with Alexandre Lacassagne, head of the laboratory of forensic medicine, to solve three major criminal cases of that time in France, which were the Richetto case, the lawsuit of the post office and correspondence of Gouffè and the assassination of the president of the French Republic, Sadi Carnot, in 1894.

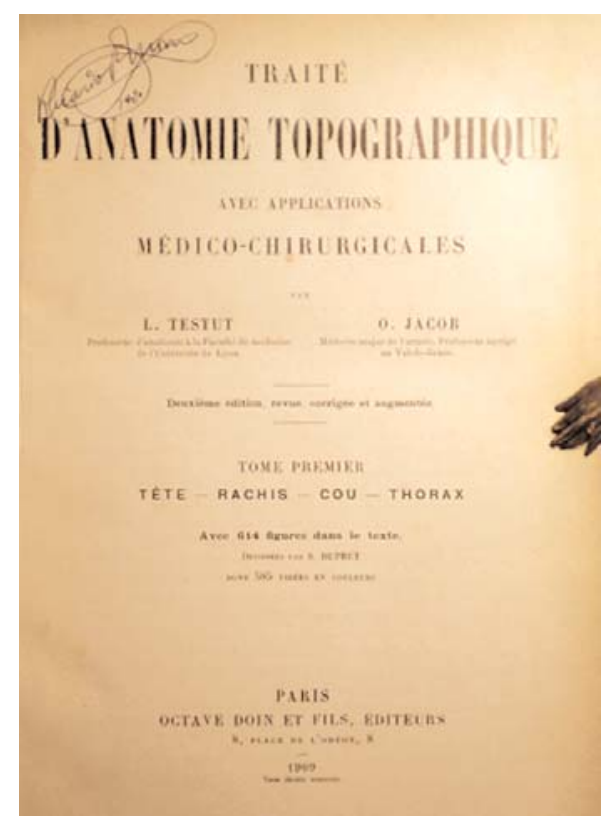

Figure 3. Treatise on topographical anatomy with medical-surgical applications; Testut L, Jacob O (1909). http://www.prbm.com/bookpics/ t/testut_29932/testut_29932_11.jpg (accessed in Feb 09, 2014).

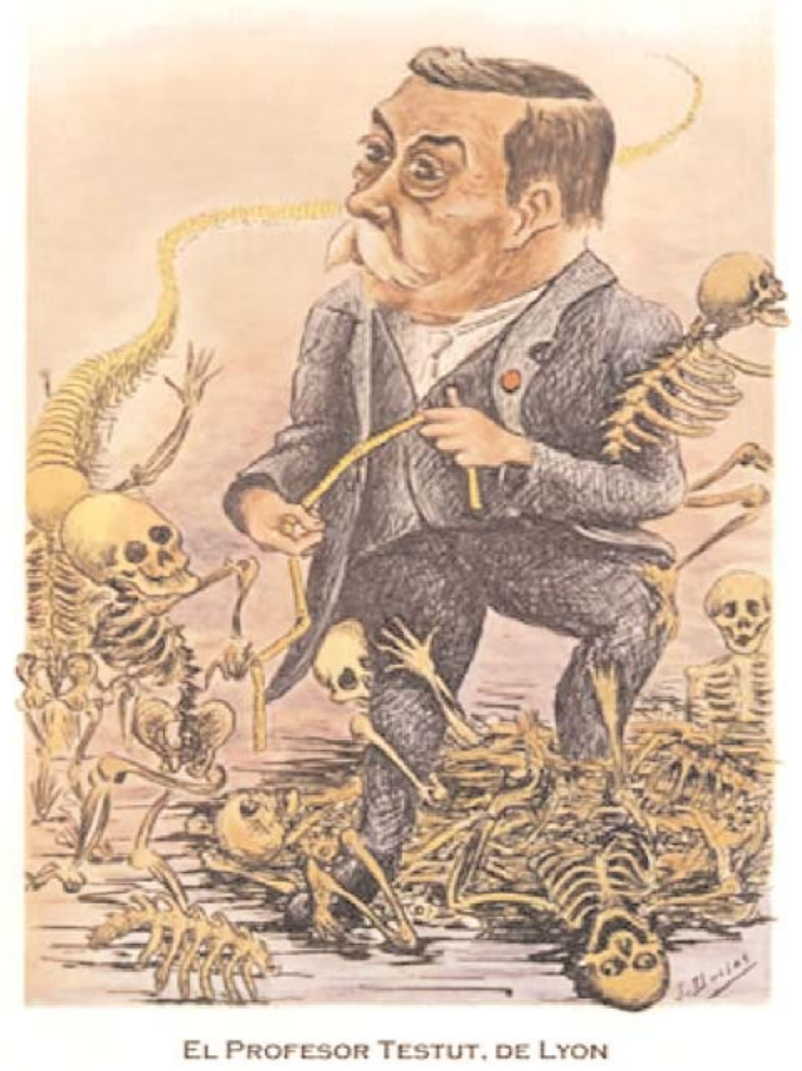

Figure 4. A cartoon of Professor Leo Testut, by Jacques Duclos for Chanteclair Journal, Vol: 102, 1912. http://www.medicinabuenosaires. com/revistas/vol72-12/n1_ch.jpg (accessed in Nov 04, 2013). 


\section{Other Activities}

During the First World War he acted as a military surgeon from 1914 to 1915, and the experience acquired in the battlefield served to update later editions of his works. Testut founded the Journal of Natural History of the Southeast of Bordeaux and the Annals of Natural Sciences of Bordeaux.

After his retirement in 1919, he devoted himself to being a medical historian, and his historic work encompassed six printed volumes and numerous articles published in journals of the southeast of France, including two volumes dedicated to the history of La Bastide de Beaumont, two other volumes dedicated to the Beaumont revolution, the fifth volume dedicated to life in the Beaumont community in the eighteenth century and the sixth volume dedicated to The Society of the Friends of the Constitution and their role in Beaumont. ${ }^{[8]}$

\section{Conclusion}

Leo Testut's oeuvre is considerable, encompassing more than 90 publications not only on human anatomy but also on anthropology, pre-history and history. He also founded and directed the International Journal of Anatomy and Histology. Leo Testut passed away at the age of 76 in Caudèran, France, on January 16, 1925, leaving a legacy and prolongation of his great oeuvre to his pupil and successor, the also outstanding anatomist
André Latarjet. ${ }^{[9]}$ In 1992, the Museum of Anatomy of Lyon was distinguished with the joint name TestutLatarjet ${ }^{[10]}$ to exalt these great cathedratics of French anatomy of the end of the nineteenth century and beginning of the twentieth century.

\section{References}

1. Rodríguez Rivero P. Eponomías Anatómicas (1938). Rev Soc Venez Hist Med 1953;1:538-9.

2. Bezerra AJC, Didio LJA, Piva-Junior L. Biographical data on the anatomist Jean Leo Testut (1849-1925). Bull Assoc Anat 1991;75:145-9.

3. Fernandes R, Babisnki M. Deus criou o homen e Testut o descreveu no seu "Traite d'anatomie humaine"- uma breve biografia do anatimosta medico Jean Leo Testut. Acta Scin Med 2012;5:17-25.

4. Testut L, Latarjet A. Tratado de Anatomía humana, 4 vol. Barcelona: Salvat Editores SA; 1978.

5. Académie Nationale de Médecine. http://bibliotheque.academiemedecine. $\mathrm{fr} / \mathrm{membres} / \mathrm{membre} /$ ? mbreid=2067. 2014 (accessed in Jan 18, 2014).

6. Romero R. Leo Testut (1849-1925). Int J Morphol 2011;29:10836.

7. Ledezma MP. Huellas de un Maestro de la Anatomia Francesa Jean Leo Testut 1849-1925. Rev Inst Méd "Sucre" LXXI 2006; 128:98-105.

8. Bezerra AJC, Bacelar SS, Piva Junior L. Quem estudou no Testut? Brasilia Med 2008;45:311-4.

9. Romero R. La Anatomía de Testut y Latarjet. Rev Soc Venez Hist Med 2013;62:62-72.

10. Musée Testut-Latarjet d'anatomie et d'Histoire naturelle médicale. http://museetl.univ-lyon1.fr/ 2014 (accessed in Nov 04, 2013).

\footnotetext{
Correspondence to: Rafael Romero Reverón, MD Human Anatomy Department, J.M. Vargas School of Medicine, Universidad Central de Venezuela, Caracas, Venezuela e-mail: rafa1636@yahoo.es; RafaelRomeroReveron@yahoo.com.ve Conflict of interest statement: No conflicts declared.
} 